\title{
Revisiting the Pandemic: Salvaging Hope and Capturing the Essence of Life in Emily St. John Mandel's Station Eleven
}

\author{
Neval Nabil Mahmoud Abdullah \\ Department of Humanities \\ College of Language \& Communication \\ Arab Academy for Science, Technology \& Maritime Transport \\ Email:nova2004@hotmail.com
}

\begin{abstract}
The present paper is mainly concerned with one of the recent postapocalyptic fictional narratives geared toward a pandemic outbreak, namely, Emily St. John Mandel's Station Eleven (2014), with the aim of demonstrating that the human condition and what makes life meaningful are what this novel is made for exploring. For this purpose, the study aims at going beyond exploring what life might be like in the grips of a global pandemic and the lengths humans will go in order to survive to get to the bottom of Mandel's philosophy, Survival is Insufficient, and probe her new imagined future.

To better frame the way Mandel establishes her post - apocalyptic setting, the present paper draws on two approaches - Tom Moylan's concept of Critical Dystopia and Evan Calder Williams' theoretical praxis named as Salvage punk to finally reach the conclusion that Mandel's Station Eleven tells more than just an apocalypse and chronicles more than just a pandemic. Perhaps paradoxically, it offers a way of finding comfort, envisioning hope, and capturing the essence of life through holding on to the best of what has been lost.
\end{abstract}

Keywords: Post - apocalypse — Pandemic - Critical Dystopia - Salvage punk Emily St. John Mandel

The present paper is mainly concerned with one of the remarkable dystopian narratives geared toward pandemic outbreak, namely, Emily St. John Mandel's Station Eleven (2014) as a case study engendering deeper contemplation of the COVID-19 crisis, with the aim of showing that the human condition is what this novel is made for exploring. For this purpose, this study 
investigates whether Station Eleven as a notable example of Pandemic Fictionadministering Tom Moylan's and Calder Williams' approaches of Critical Dystopia and Salvage Punk, respectively - exhibits more nuanced, optimistic territories than many end-of-the world fictional narratives, internalizes applicable moral lessons, provides good food for thought and for finding our way through dystopian scenarios, and serves as a meaningful reflection through which humans can build a better future.

For this purpose, the study seeks to answer the following research questions: First, how would life be like in the grips of a global pandemic? Or, more precisely speaking, what are the politics of disaster in Pandemic Fiction? Second, in what way does Mandel's Station Eleven remind us that people are not just numbers- death rates or statistical reports? In other words, in what way is the featured pandemic in Mandel's novel a symptom of something different, something profound? Third, when reality becomes chaotic, what would survive or could be salvaged - according to Mandel - to recover a sense of normality, rebuild, and recreate the world a new? Fourth, by drawing on Tom Moylan's concept of Critical Dystopia, how does Mandel's Station Eleven - perhaps paradoxically-provide a way of appreciating the graces of everyday life, finding comfort, and envisioning hope? Fifth, in what way does Mandel's Station Eleven provide an example of what Calder Williams has termed as Salvage punk? Finally, amid this dreary scenario, does Mandel's Station Eleven succeed in rising above the gloominess of the usual post-apocalyptic novels, contribute to deconstructing nihilistic spirit, and assist in reconstructing alternatives?

To narrow the search on dystopian pandemic fiction, the researcher does not only seek to find a literary work that best represents this genre, but that best parallels what follow the COVID-19 crisis-a literary work that is tempered with just the right amount of hope. As such, the present paper examines Emily Mandel's Station Eleven (2014) - a novel that mirrors our current reality and captures the panic and anxiety of Corona virus as cities grind to a halt and death tolls jump through two distinct critical approaches: Tom Moylan's concept of Critical Dystopia and Evan Calder William's theoretical and aesthetic praxis named as Salvage punk. The aim is to find the revelations hidden beneath and demonstrate that the critical and emotional insights offered by the pandemic fictional world are made possible only through uncovering the terrors of the present. 
The rationale or the basic underlying reasons behind choosing this area of study is the researcher's growing preoccupation with the apocalypse and the sudden outbreak of COVID-19 pandemic. But what actually inspires the researcher even more is the rich narrative possibilities and ideological dimensions offered by such experiences. Moreover, the text under consideration is - according to the researcher's view - a proper choice for those looking for a pandemic novel that stitches truths about humanity into the fabric of its unfamiliar worlds. Thus, this paper - it is hoped -provides a lens for viewing the politics of disaster and the non-therapeutic dimensions of the fears associated with a pandemic. More importantly, the study attempts to foster social change, to incite a more ethical attitude toward ideologies that could speed up our psychological and social dystopias, and to implore us to work for a better world than the one the text so vehemently depicts.

Eventually, the researcher reaches the conclusion that in the backdrop of a pandemic where the world seems to shatter right before one's very eyes, it seems as though it would be very easy to simply accept it and give up. However, what Mandel has managed to assert that in the midst of this horror survivors require more than their basic needs met. In the midst of pandemic, decency will emerge, survive and endure, and humanity can triumph and preserve its virtues through all disasters as long as there is life.

Having considered the objectives, research questions, methodology, rationale, and significance of this paper, the researcher deems it appropriate to detail several threads that are relevant to the development of the paper's line of inquiry, for the sake of better framing the paper's analysis. As such, the present paper starts with reflecting on the millennial obsession with apocalypses, the threat of plagues that have shaped the psyche of humanity for times immemorial, and the aftermath of the Corona virus chaos. Once this ground work is laid, the paper then moves on outlining the tangible increase in attention to dystopian or post - apocalyptic fiction, and then considering the politics of disaster in an unremittingly bleak sub-genre of dystopian fiction, namely, Pandemic Fiction or Outbreak Narrative, that has recently gained a surprising momentum. The researcher then strives to lay a basis for understanding Dystopias through identifying the following: what is meant by Dystopian Fiction? what kind of social commentary do these fictional narratives make? what purposes do they serve? what sort of warnings do they present? what is Moylan's Critical Dystopia about? and in what way is Moylan's emphasis on 
"uncovering" is similar to Evan Calder Williams' Salvage punk? and how both concepts are ,after all, appropriate frameworks and useful ways to approach Emily St. John Mandel's Station Eleven and to look at the way her apocalyptic novel functions.

To start with, the humans' obsession with apocalypses is nothing new. For millennia- since the world's inheritance - many religions, cultures, superstitions, and ancient societies have been created on the basis of apocalypse and have been imagining and predicting the end of the world. Since the dawn of time, the pious people long proclaimed how they were messengers of God and those who would not obey them would be penalized in a harsh way by God Himself and that moment will be the Doomsday or Apocalypse. The opportunists, on the other hand, at the time of any catastrophe like war, famine or draught always unethically took immediate advantage and disseminated an incoming apocalypse so that the weak-minded crowd could easily be manipulated (Seidal 2019: n.p.). The difference between then and now is that humans then predicted the apocalypse to happen at around 1000-2000 years later, but lately humans have been predicting for an apocalypse within a few years (Harmon 1999: n.p.).

The world becomes apocalyptic when there is an overwhelming sense of chaos, uncertainty, fear, powerlessness and fatalism, and when the traditional values, beliefs, and societal constructions no longer resonate with the emerging spirit of our time. Accompanying large cultural and technological shifts, apocalypses are depressing. And it is not just because humans and non-humans are likely to wind up dead, but because apocalypses mark the end of an epoch, the loss of a former way of life, the loss of hope and control - of meaning itself. In an apocalypse, countless of human generations worth of innovation, problemsolving, altruism, and will end in nothing. Everything humanity has ever created will become futile, including man's smallest contributions (O'Leary 1994: n.p.).
A world of fear and treachery and torment, a world of trampling and being trampled upon, a world that will grow not less but more merciless as it refines itself. (Orwell 1949: 279).

The apocalyptic landscape thus is one where the virtues of the individuals and societies are destroyed in the name of development and control.

The apocalyptic idea that this world is a constant threat is quite frightening. On the other hand, this same idea is kind of appealing to a lot of 
people. So, why humans are so fixated with the end of the world scenarios? Actually, the fascination with 'the end of the world' gives humans a way to pursue what they are most afraid of, to survive against all odds, and to master and conquer death which is inescapable. Moreover, apocalypses help humans unite and face the end together. Besides, a little injection of apocalyptic scenarios would be alluring. Apocalyptic tales can lift us out of the boring everyday life and involve us into dangerous realities that have hair-raising - but happy - endings. Likewise, humans - in confronting something that is horrifying - are thus reassuring their survival. Nevertheless, while these apocalyptic scenarios sound very dramatic, they are psychologically comforting - they validate, and rationalize the psychological unbearableness of our our complete demise, and show us that there will 'always' be a happy ending, help us know our enemy well enough, and understand ourselves better as a whole. Eventually, they may serve another purpose - they wash away whatever atrocities we have committed on this planet and an each other by making a real world hard reset (Beebe 2013: 11-14).

The Apocalyptic narratives grow in the wake of WWI, WWII, and the cold war nuclear arms' race. They fall into two simple before - and - after categories: the apocalyptic and the post - apocalyptic. Both genres tend to follow characters usually tasked with navigating the death traps of an apocalyptic world and trying to survive a devastated landscape. Nevertheless, in the apocalyptic genre the disaster occurs during the course of the story in a catastrophic scale, and it usually ends with a miraculous salvation event, often sacrificial. Coming from the Greek 'Apo' and 'Kalypto' which means to 'take away' and 'to cover and hide', the apocalypse is a moment of punishment or a final judgment for human sin and hubris (qtd in Demerjian 2016:6). On the other hand, post- apocalypses signify a continuation of life after the apocalypse has already happened. Regardless of how horrible they may be, post-apocalypses are not ends, but struggles for continuation (Stringer 1996: n. p.). The common themes that govern these fictional narratives include circumstances that lead to mass disruption and wide spread demise. Among the apocalyptic scenarios: environmental mega-disasters, run-away climate change, alien invasions, cybernetic revolt, nuclear holocausts, gluttonous zombies, resource depletion, extraterrestrial collision, global wars, life- threatening pandemics and mutant viruses - are the most obvious symptoms (O’ Leary 1994: n. p.). 
In tandem with the millennial obsession with the apocalypse, the threat of plagues has always been humanity's major concern throughout the course of history. These infectious outbreaks - whether bacterial, viral or parasitic - have long claimed the lives of unthinkable number of people worldwide. Sometimes changing the trajectory of history, and other times, demonstrating the demise of entire civilizations, plagues - since pre-historic times till modern ones - "are like imponderable dangers that surprise people (6)," Gabriel Garcia Marquez maintained. "They seem to have a quality of destiny (6)." Malaria, tuberculosis, leprosy, small pox, plague of Athens (typhoid or typhus), Antonine plague, Plague of Justinian, Black Death, Measles, Cholera, HIV/AIDS, Sars, Mars, Zika, and Ebola are among the major life- threatening plagues that have long ravaged human populations (Oswaila \& Kavita 2021: 5-8).

In the realm of the above - mentioned infectious diseases, a pandemic is the worst case scenario. Not a word to use unthoughtfully, a pandemic is an epidemic that has spread beyond a country's borders, affecting multiple countries or continents worldwide (WHO 2020: n. p.). That's when the disease is officially called a pandemic. Among the recent deadliest global pandemics - and rare among viruses- for its over whelming sudden global eruption, and devastating toll on human lives is the ongoing COVID-19. Shaking the whole world to its core, the uncontrollable world-wide outbreak of COVID-19 has touched every country, every sector and every individual. UN Secretary-General Antonio Gueterres conceived it as a global recession of "record dimensions" when he declared: "Our world faces a common enemy. We are at war with a virus" (UN News 2020: n. p.). The challenge for many countries was thus tremendous: Some countries struggled with a lack of capacity; some countries struggled with a lack of resources; while others struggled with a lack of resolve.

With the number of daily new cases, and with the propagation of fear, chaos, and despair, the whole world was instigated to carry out a combination of unprecedented precautionary hygienic measures to contain, trace and control the pandemic (BBC 2020: n.p.) These measures incorporated personal hygiene measures, rigorous testing, social distancing, stay-home orders, wearing masks, prohibiting mass gatherings, proclaiming over seas travel bans, creating quarantines and mandatory shutdowns of transportation systems, public offices, and other activities. Since the virus has diffused almost everywhere in the world, however, such procedures alone can't abort the pandemic. As it is logical that the larger the scale of an outbreak, the larger the impact and magnitude of its 
sequelae. "There are decades when nothing happens and weeks when decades happen (Fareed 2020: n. p.). "

The millennial obsession with the apocalypse and the 21st century epidemics, sparing no one, rich or poor-Sars in 2002, Mers in 2012, Ebola in 2014, and recently the emergent COVID-19 pandemic -have thus inspired new forms of dystopian narratives about post - plague desolation, inchoate fears, looming demise, deserted cities, and devastated landscapes. Whether peering into a distant past or leaping into the future back to the present, some of these dystopian pandemic narratives beside serving as nightmarish articulations about what life might be like in the grips of a global pandemic and the lengths humans will go in order to survive - this study maintains - are ultimately hopeful narratives, and speak to more than our pandemic-frenzied moment. Though featuring imaginary bleak futures, some of these dystopian pandemic narratives evoke more than the weary feeling of life slipping away, tell more than just apocalypse stories, by weaving beautiful stories of human relationships amid devastations, genuinely making sense of chaos, and looking upon the world with different and optimistic eyes. Apart from exploring the feeble beauty of the world we live in, and questioning the structure that our society is built upon, these dystopian pandemic narratives are relevant case scenarios tempered with just the right amount of hope though they have all the stress and intensity of the typical dystopian tale.

Before embarking on explaining the features of the above-mentioned Outbreak Narratives, one has to outline, in the first place, what is meant by Dystopias. Dystopias are recognized as the negative counterparts of utopias: A form of prophecies offering a bleak vision of the future or near future, a combination of the Greek prefix (dys-), meaning "bad" and (topos), meaning "place", a dystopia thus literally means a place where the conditions of human life are extremely imperfect, where no one would want to live, where one's rights, freedoms and happiness would be gone, and where the environment would be devastated (Alihodižvić 2016: n. p.). As defined by the Encyclopedia of Science Fiction, dystopias depict negative views of the world we inhabit "to provide urgent propaganda for a change in direction (Stableford 1993: 360362)." Dystopias - as pointed out by Margaret Atwood - are often "more like dire warnings than satires, dark shadows cast by the present into the future (94)." 
Meanwhile, Dystopian fiction is a form of speculative story telling that comes as a response to Utopian fiction (Lepore 2017: n.p.). While Utopian fiction portrays what many would call a paradise - a perfectly organized, imagined society, free of war, poverty, oppression and environmental decay, Dystopian fiction - by contrast - depicts societies in cataclysmic decline, with characters battling environmental disasters, extreme suppression, lethal diseases, mass poverty, technological control, limited resources, totalitarian governments, or forever wars (Gottlieb 1994: n. p.).

The worlds of dystopian fiction do share many of the same features. They express their authors' concerns about issues of humanity and the inherent flaws and failures of those social systems previously considered ideal (Gottlieb 1994: n. p.) - the reason they are often considered as critiques by Margaret Atwood (Mead 2017: n.p.). Usually set in the near - rather than the far - future most dystopian settings are inevitably linked to a totalitarian state apparatus exercising strict control over all aspects of the lives of its inhabitants. These inhabitants - living in a dehumanized state, under constant surveillance, and deprived of freedom, information, and independent thought - thus come to recognize the negative aspects of the societies in which they live in. Hence, they often feel trapped and struggle to escape (Booker 1994: n.p.).

Having long had a place in the canon, Dystopian fiction has also provided a fertile ground for writers to create an enduring sub-genre named as Pandemic or Outbreak Narratives that have recently experienced a huge surge of interest. The course of Outbreak Narratives' is usually well - defined. Humans are at war: Man vs. microbe. Set against the backdrop of (historical or imagined) plagues or pandemics, Outbreak Narratives are cautionary tales that follow formulaic plots of disease emergence, identification, and containment. Epidemics "follow a plot line of increasing and revelatory tension, move to a crisis of individual and collective character, then drift toward closure (Rosenberg 1989:2)." Displaying the threats of mass destruction, limited control, overtones of divine retribution, wicked villains and innocent victims, novels featuring pandemics are thus real, but the narrative blurs fact and fiction. Every story of epidemic, Jill Lepore writes in the New Yorker, is a story of "man made brute (2020: n. p.)." But then -as Lepore affirms- the existence of these narratives, no matter how grim the tale, is itself a clue, verifying that "humanity endures, in the very contagion of reading (n. p.)." 
A point worth mentioning, the perspectives of this sub-genre's writers vary and the human responses are just as varied: Scientific ingenuity, illogical paranoia, defeated acceptance, heroic sacrifice, or sheer survival at any cost. Omnipresent is the impulse to blame a segment of society for the outbreak, and stigmatize their behaviours and life styles that either carried or ran a higher risk of transmission (Self, 2020: n.p.). Among the best fictional narratives featuring pandemics are Albert Camus' The Plague - one classic of the genre, José Saramago's Blindness, Mike Chen's A Beginning at the End, Peng Shepherd's The Book of M, Lawrence Wright's The End of October, Rebecca Makkai's The Great Believers, Gabriel Garcia Márquez's Love in the Time of Cholera, Charles Wheelan's The Rationing, Ling Ma's Severance, Geraldine Brooks' Year of Wonder, Emily St. John Mandel's Station Eleven, and others. Unsettling and memorable, these novels - ranging from the historical to the futuristic - carry the same uncertainty as our 2020 reality of COVID-19 (Self 2020: n.p.)

Though functioning as cautionary tales presenting alternative world scenarios and projecting a relatively worse dystopian social order than the current experienced one, some of these dystopian pandemic narratives are not completely pessimistic since they offer glimmers of hope through open-ended narratives, especially in the critical dystopias of this century. For one way of being anti- utopian is to be utopian: To keep imagining that things could get better, and moreover to imagine how they might get better. As Viera definitely maintains: "Dystopias that leave no room for hope do in fact fail their mission $(2010,17)$ ", and it is especially the Critical or Open-ended Dystopia - a subset of dystopian fiction- that leaves fertile ground for utopian explorations.

A concept originated by Lyman Tower Sargent (1994:9), but once more introduced into the mainstream discourse by Tom Moylan in his book, Scraps of the Untainted Sky (2000), Critical Dystopia is

the uncovering of a non-existent society ...

that includes at least one utopian enclave or holds

out hope that the dystopia can be overcome

and replaced with a utopia (Moylan 2000: XV).

Unlike the traditional dystopia, Critical Dystopia - as a variant of Utopia's fictional discourse and one of its most important developments - is thus not preoccupied with the melancholy accounts of the degeneration (2000: 275-276). For what takes the precedence in between all the dreary events and societies it 
portrays is the preservation of the utopian potential for renewal, radical change and a better future. Critical Dystopias thus endeavor to search for "traces, scraps, and sometimes horizons of utopian possibility (276)."

Though embedding a stubborn utopian ethos, Critical Dystopia mainly attempts to interrogate the ills of the existent order, uncover and condemn the terrors of the present, and exemplify what is needed to transform the status quo while enabling its characters to find and pursue potential ways out of the dystopian imprisonment (Moylan 2000: 198-199). Fortunati defines the concept - which he sees as crucial to our salvation - as "hope towards the unfulfilled, unachieved utopia, showing the reader a road must start in the present (qtd. in Vieira 2013: 29)." Though hopeful, Critical Dystopia is not a push for a utopia in the conventional political sense, nor is it a revival of the catastrophic systems that have plagued humanity. Instead, it is an acknowledgement of humanity's inherent need for improvement, while encouraging a practical approach to begin in the present. Hence, what is needed- as argued for strongly by Baccolini, Raffaella and Moylan- is reading Critical Dystopias as texts sustaining a utopian drive, and offering virtual possibilities to find and actualize. For classic dystopias maintain utopian hope outside their pages (2003:7). The present paper thus - by utilizing Moylan's concept of Critical Dystopia-investigates the way through which Mandel's Station Eleven makes something subtle and unusual out of the grim horror or dystopia. She offers hope - not through a reawakening of a worn out past, but through a new imagined future in which the traditional features and borderlines of relationships, values, identity, and society can be reshaped in "another world just out of sight (Mandel 2015:333)." Rather than mapping out the resulting chaos of the pandemic, Station Eleven articulates utopian possibilities and stresses the importance of personal and collective imagination for choosing among alternatives. This has been attained through Mandel's depiction of groups of survivals with fragmented personal experiences, in their attempts to come to terms with what they have lost, figure out how to rebuild, and recover a sense of normalcy.

Exercising the same emphasis on "uncovering" and incorporating the same transformative utopian impulse is Evan Calder Williams' Capitalist Apocalypse or Salvage Punk. As Williams puts it, the world is not heading for an apocalypse, the apocalypse has already happened: "The world is now irrevocably structured as an apocalyptic waste land (2011: 36)." As such, for Williams, current post apocalypse is defined by the distinctive kinds of probing, 
uncovering, and thorough critique of the destructive realities ... that have wrecked our lives. It is defined as well by the construction of a new world from sorting through its apocalyptic wreckage to unearth the revelations hidden underneath (Mark 2018:1-2).

Recognizing the apocalyptic nature of this epoch, Williams has invented a theoretical and an aesthetic praxis named as Salvage punk. This praxis becoming one of the fundamental structures of thought that carve how we visualize future possibilities - takes the left overs of the capitalist mode of production, with the aim of recapturing utopia under the colossal junk of capitalism's throwaways. A post - apocalyptic vision, Salvage punk thus is a manifestation "of a broken and dead world," littered with both the dream remnants and "real junk of the world that was" (Williams 2011:19). In other words, Salvagepunk comprises picking through the "junk", acknowledging "left overs", encouraging "waste sorting and value recuperation", stimulating "repurposing, detouring, and scrapping (19-20)," and promoting a return to "the repressed idiosyncrasy of outmoded things (31)," while overlooking their monetary, or capital value. A key feature of Savage punk thus is that it takes place in "a world of stealing from the ruins, robbing the graves, and rearranging the left overs (70)." It recuperates or searches for value in what has already been destroyed. But the question is: why salvage? "Because we are wrecked (34).". Because we need a strategy for ruination - a strategy that "prevent (s) the ship from sinking" and "join(s) [the] realm of dead objects (34)." And, instead of reimaging these dead objects as something different from what they are, Williams maintains, actually existing objects are reconstructed into something new. Thus, Salvage punk is about "choice and construction (70)." This construction occurs by turning the remaining objects into what they are never meant to be, or by rendering them do what they are not intended to: Objects "weirdly incommensurable with the purpose for which they were designed (21)". So, basically punk is the invention of new rules, new values, new objects, new people, and discarding the old ones.

The praxis of Savage punk is thus- as maintained by Williams - the proper genre for the current epoch and the best mode of resistance to counter the imminent demise of our world brought about by our own hubris. It not only assumes that "it's already been burnt, already lost at sea (Jameson 2003: 76)", but it reckons that it is never really the end, by exhibiting how "we can only begin again from here (36)," and by demonstrating how punking people and 
objects into something new might lead to something better. Or, as Mieville says in an interview, "It is too late to save, but we might repurpose (2018: n.p.)."

Though its punking expectations are scary and though it opens up possibilities for rebellion, Williams' Salvage punk or Capitalist Apocalypse thus looks for the alternate stories or the hopeful realities of this ruined world. Most importantly, Salvagepunk discards the past as taboo and forgotten, by struggling against "current trend lines of nostalgia, the melancholia of buried history," and permanent "mourning for radical antagonistic pasts (2011:20)." Accordingly, what is needed - Williams asserts - "... is an apocalypse... an end with revelation", a "lifting of the veil (5)", "a work of construction", "a production of valueless times" (42) to see what values might emerge. Nothing is ever really junk, Williams puts it. The key question for "salvage-thought" is how can humans rebel against the historical metanarratives that have led them to this present reality, and how can humans repeat differently. Humans cannot stop repeating- Williams maintains-but they should be concerned with how to look for the possibilities and alternate stories within those metanarratives, and "how to make from the broken same the livelier constructs of something other (69)." The praxis of Salvage punk thus offers its readers the opportunity to trace all that capitalism works to conceal; acknowledge its remnants past their capital value; uncover hope in the junk heap of the past and the present; unlock a future that capitalism has rendered un imaginable; repurpose a new landscape with a locus of hope, and track down a utopia buried in dystopia.

Witnessing a resurgence in our days of COVID-19 panic, Station Eleven Emily St. John Mandel's fourth novel, 2014 blockbuster hit, and long listed post apocalyptic text for a US National Bank Award - has acclaimed the Canadian author to literary stardom. Set in the days of civilization's breakdown, the novel opens on one snowy night where an aging, famous Hollywood actor, Arthur Leander, has a fatal heart attack, and drops dead on stage during a performance of Shakespeare's King Lear in Toronto. Jeevan Chaudhary, an ex- paparazzo and now a paramedic under training, attempts to save Arthur with CPR. Among the people on the scene is Kristen Raymond, an 8-year-old actress, playing a minor non- speaking role as one of Lear's children. The crew members of Lear's performance think about notifying Arthur's family, especially his young son Tyler who lives in Israel with his mom, Elizabeth Colton, and connecting with Arthur's lawyer. There is hardly time for people to grasp this shock when disaster happens in the form of a super - flu pandemic. Receiving a call from a 
friend named Hua- a doctor alerting him to the imminent outbreak of a global pandemic, the Georgia Flu, Jeevan stocks upon supplies and survival equipment and goes to stay with his disabled brother, Frank (who later on commits suicide to allow Jeevan to travel in search of survivors and resources).

News of Arthur's death then spread to his former wives through Clark Thomson, an aspiring actor and Arthur's best friend. Happening to be on the same flight from New York city to Toronto to attend Arthur's funeral, Clark, Elizabeth and her son Tyler - having now nowhere to go - create a settlement in the airport with the other passengers. Meanwhile, Clark becomes the guardian of the Museum of Civilization, gathering antiquities such as i phones and laptop computers. Unlike the airport survivors who fit in their new life, Elizabeth and Tyler adopt religious fanatic attitude believing that the pandemic occurred for a reason and let off those who were good. After two years, they leave the airport with a religious cult.

As the novel alternates between depictions of the pandemic as it unravels and two decades later when the world is still reshaping, Arthur's emergence as an actor and Kristen's post pandemic life draw the attention of the narrative. Two decades after the eruption of the Georgia Flu and the destruction of civilization, there is no Canada, no United States. All countries and borders have disappeared. The novel then jumps ahead concentrating on the Travelling Symphony, a band of musicians and Shakespeare's performers roaming from town to town - the waste lands of what remain. Entertaining the people with musicals and Shakespearean performances - as this, they believe, what audiences prefer, the Travelling Symphony adopts a motto: Survival is Insufficient.

Joining the Travelling Symphony as a teenager and remembering little of her life before the pandemic, Kristen holds on tightly to a two-volume set of comics given to her by Arthur before his death, titled Dr. Eleven. Obsessed with actor Arthur Leander, whose death she beheld as a child, Kristen saves magazine clippings about Arthur that she finds in deserted houses. The clippings relieve Kristen because they place her in a simpler, easier, and more secure world to live in.

The novel then moves back to a time before the pandemic where we learn about Arthur's life, in particular his first marriage to an art school graduate named Miranda. We witness (the now deceased) Arthur and Miranda meet, fall in love, and get married. We learn that it is she who has written the Dr. Eleven 
comics*, working on them as a hobby over many years. She has once given a present of the first two issues to Arthur, who in turn has given them to small Kristen. Later, at a dinner party in Hollywood, Miranda meets Clark, and she realizes that her marriage with Arthur is coming to an end, as he is having an affair with a movie star in his current movie: Elizabeth Colton (who would become later on his second wife). Realizing this, Miranda then meets Jeevan, who works as a paparazzo and who has duped her into an unfavourable snapshot.

The novel flashes forward to the twenty - fifth year after the Pandemic where we witness the Travelling Symphony arrives at a town called St. Deborah to collect two members of their band, Charlie and Jeremy, who were missed two years ago. Upon arriving, the band is troubled to find that their friends are missing, that St. Deborah has changed, and is - now - under the tyrannical control of a dangerous and zealot man calling himself a prophet who kidnaps the young girls he claims as his 'brides'. Swiftly leaving St. Deborah and going offroute to the Museum of Civilization, a settlement where they believe they might find their lost friends, the band finds a young escapee who fled St. Deborah, as she was promised to the prophet as his wife. Later, the entire band has disappeared, leaving only Kristen and her friends August and Sayid (whom the prophet's men have been holding). Frightened, Kristen August and Sayid head to the Severn City Airport, hoping to be reunited with others. However, Kristen is soon tracked down by the prophet himself. Just before the prophet almost kills her, a younger guard kills the prophet. The trio finally get together with Charlie, Jeremy and the rest of the band. As to Clark, who has lived in the museum for two decades, recognizes Kristen, and the prophet -who is in fact Tyler Leander. Clark takes Kristen up to the watch tower of the airport, where there is a town to the south with electric lights, showing that civilization is beginning to be reconstructed. Later on, Kristen leaves with the Travelling Symphony for this town to the south. She gives a copy of her comics to Clark's museum before leaving.

Reading Station Eleven as a classic dystopian pandemic novel - where a lethal virus brings the world to an end, the recent study discerns that Station Eleven is a post-apocalyptic novel featuring a catastrophe of enormous

\footnotetext{
${ }^{*}$ Dr. Eleven Comics: A story of humans who have fled earth just prior to its conquest by aliens. A human made planet where people live in perpetual twilight, Station Eleven's civilization is plagued by 'the underworld," inhabited by dissatisfied individuals who want to return to earth under any circumstances and who snatches the residents of Station Eleven away from safety when they least suspect it.
} 
proportions and overwhelming consequences. Set in a dystopian scenario, where everyone has died and everything has been brought to an end, Station Eleven's radical social and economic disruption is not unlike our own COVID - stricken landscape. However, the post Georgian Flu world is much more drastic and dire: The pandemic here is not a gradually built, just immediate doom. Thus, Station Eleven is dystopian as it interrogates the present, offers warnings and provides prophecies about the future. It is dystopian, as well, as it evokes the weary feeling of life slipping away within the context of a fallen world. It is a world about pain, trauma and death.

No more pharmaceuticals. No more certainty of surviving a scratch on one's hand, a cut on a finger while chopping vegetables for dinner, a dog bite. No more flight (37).

It is a world about absence, emptiness and loss.

No more internet. No more social media, no more scrolling through litanies of dreams and nervous hopes and photographs of lunch, cries for help and expressions of contentment and relationship - status updates (38).

What remains in this diminished world and "over grown wilderness" are "ghost cit[ies]" (274), "ghost plane[s]" (280) whose passengers never disembarked, "[r]usted - out cars ...abandoned where they'd run out of gas" (133), groups of travelers who are diverted, and quarantined in a remote air post, "ferals" who raid the Mexican restaurant for food and the gift shop for clean clothes and scented candles to light the bathrooms, and religious cults who threaten to usurp peaceful communities. The scale of the post - flu collapse and the remnants that fill the landscape, thus, don't just signify the end of the world these people themselves knew, but also the end of a much longer past of what Mandel calls the modern world. What is ending with the flu - Mandel helps us understand - is the capitalist world system. Through this dystopian setting, readers are thus shown how the novel's apocalyptic pandemic scenario is intertwined with this world system; and how - in a world wrecked by a disease - the survivors relinquish their hold on the planet, become fragile and just visitors. They are made to think, imagine and envisage how the present can change into something very unpleasant. 
Reading Station Eleven through the lens of Tom Moylan's Critical Dystopia, one finds that Station Eleven - though considered among the classic Dystopian Pandemic narratives - pushes against the usual format of the dystopian genre. For, unlike many dystopian narratives that focus on the society's decline and the harsh struggle that immediately follows the collapse, Station Eleven is more concerned with scrutinizing the human aspects that come into view within the context of a cold, barren, bleak and disrupted pandemic world. It is more preoccupied with ushering in a utopian new world which makes sense of everything that happened before, and with probing the ways through which humans can interact with art, religion, civilization, memories, and relationships. Accordingly, Station Eleven - this study maintains - tells more than just an apocalypse and chronicles more than just a pandemic. Less interested in the specter of the end, Mandel's emphasis is on the present and its ethical value- the moment in which the survivors take choices that inform the future. Though showing that this flu has wiped out $99 \%$ of humanity in a matter of days, Mandel's novel bypasses the clichés of horror, chaos, dystopia, and the daily struggle of vulnerable human beings lacking the basic amenities of life. Undoubtedly, catastrophes have provided rich fuel for Mandel's fiction. "A disaster is a very efficient way to create a lot of drama (Hill 2020: n.p.)," she says. Mandel prefers, though, to allow world events to sit in the background of her work. Thus, though the portrayal of the end of all things is the novel's focus point, this end is used by Mandel as a literal 'Ground Zero', not as the only thing (Barnett 2016: n.p.). That's why her novel does not devote that much time to the details of its particular pandemic. We learn, as the novel progresses, that this flu causes respiratory failure, is highly contagious, and - within only three weeks comes to grind the whole society to a halt: Air travel is banned, cell lines are jammed, electricity is cut off, internet is erased, and television stations have stopped. However, less interested in the "why" of the end, Mandel is more interested about the "what" it would be to live in the after math of the collapse, the "how" of what might actually happen, and the "how" of making sense out of chaos. Mandel has detailed so much the world of two decades after (when the worst is over and the few remaining survivors struggle to stick to civilization) and a few years before (when Arthur slowly succumb to the rot of fame). As such, Mandel renders her readers truly feel for the millions who are dying, instead of considering them as statistics. 
Reading Station Eleven through Evans Calder William's notion of Salvage punk, the present study discerns that Mandel has managed to portray a postapocalyptic world littered with endless layers of leftovers. And, while the effects of the Georgia Flu are devastating, the survivors are shown attempting to survive by picking through the wastes of the earth, the mountains of junk, and the remnants of history. Sifting the rubble, these survivors take what is useful and discard the rest, combine and repurpose objects, ideas and ideals from the past based on their value within hostile environments. Their aim is to uncover secrets from the pre-apocalyptic world - hidden in the rubble of catastrophe, and search for value in what has already been destroyed.

Mandel - recognizing the apocalyptic nature of the present, and rather than lingering on the devastation that follow the Georgia Flu - takes up the leftovers of the flourishing wastelands of late capitalism for the sake of seeking moments of beauty amid destruction, redeeming the pre-apocalyptic world, minimizing the capitalist apocalypse, and building a new better world. What was lost in the pandemic, Mandel believes, "almost everything, almost everyone, but there is still such beauty (Mandel 2014:57)." Aiming to prove that destruction comes in the guise of beauty, Mandel attempts - throughout the text - to pose these questions: what would life be like and what would survive in a scenario like this? Or, more precisely speaking, what remnants of the past or aspects of the pre-apocalyptic world that should be seriously sought and desperately yearned for? what needs to be redeemed, repurposed, or preserved after an apocalyptic event? And, what kind of salvage is envisioned?

Drawing on Evan Calder William's Salvage punk, Mandel calls for a "permanent visibility of the hidden $(2011: 156)$." She seems to uphold - in Station Eleven - that there are things that are important than mere survival, and that last longer than the hyper-technological brief stage of human history. They are the things - Mandel maintains - that we think of as the highest and most exalted expressions of our culture: art, faith, civilization, memories, and human relationships. By keeping these aspects alive - Mandel believes - the virtues, modernization, and spirit of the collapsed civilization will be kept alive as well. Seeking to redeem these aspects is what distinguishes man from beast, what truly renders people together, and what enables them to have close familial bonds that would not have been happened had they just been together for hunting and seeking shelter. No matter how the extent of catastrophe is, Mandel has shown how the survivors need to have a means to alleviate tension, and to 
have a way to salvage what is valuable for the sake of retaining their humanity. This is the strength of Salvage punk. Though scary as it leads to new objects, new people, and indicates new rules to follow, new directions to go, and new ways of being, Salvage punk - as manifested in Station Eleven - can find the "freewheeling creative force" (Williams 2018: n. p.), in the words of Llanso - in the detritus of the apocalypse of the present. And, the survivors - in their efforts of thinking about how to survive - consciously or sub-consciously start to bring together their old lives before the collapse and make them resemble the real thing as possible. However, they come to realize that they are not quite the same. As such, Mandel's Station Eleven focuses on such repurposing in what comes next.

Analyzing Mandel's Station Eleven in the light of the previously discussed theoretical sections, the present paper contends that Mandel sets up a major question about her world: What would survive - or can be salvaged and repurposed- in a scenario like this? In an attempt to answer this question, Mandel starts her novel in a modern world much like our own, filled with people struggling to determine their place in life. But suddenly a devastating outbreak destroys the global population. Outlining the aftermath of the chaos, Mandel providing an example of what Evan Calder Williams has termed Salvagepunk and aiming to do something a bit different - strives to make the survivors figure out how to seek and create beauty; how to recover a sense of normality; and how to rebuild regardless of the catastrophic event that seeks to define them.

To begin with, as no 'end of the world' novel can avoid raising issues of survival, Mandel is interested on how people manage to survive in the aftermath. Thereby, she negotiates several aspects of surviving the flu. Some survivors are happy to embrace survival as a matter of luck - like Clark who assesses how lucky he is passing through contaminated airports and passengers; and Jeevan whose survival is attributed to a friend's warning call. Other survivors give themselves the right to determine who is saved and why- like the prophet who views the diverted flight as an archetypal Noah's ark saving people for a divine purpose. Meanwhile, others regard that survival can be attained through skill and decisions rather than through chance or purpose. Among of which is the hunter who provides food for those in the terminal; Kristen who tattoos and documents the people she has to kill upon her arm; Jeevan who reacts quickly to get food and blockade himself and his brother in an apartment; and Frank who sacrifices himself to assist Jeevan's survival. 
Despite the afore-mentioned, the strength of Mandel's novel is that she disseminates the notion of 'living is not just survival', as the Travelling Symphony's motto points out, "Survival is Insufficient (Mandel,2014:61)" meaning that there is more to life than just making it through the hard part; there is a whole world after it that needs to get rebuilt. Taking great lengths to know exactly what else is needed to fulfill our lives, and what cultural additives mean to us, Mandel maintains - throughout the text - that true survival is living a life full of art, faith, memory, passion and human connection.

In this unforgettable, haunting, and almost

hallucinatory portrait of life at the edge, those who remain struggle to retain their basic humanity and make connections with the vanished world through art, memory, and remnants of popular culture (Gilbert 2014:100).

Mandel's first way to maintain hope and repurpose life within the story is represented by her continuous stress upon the power of art. Through the grim backdrop where even electricity and technology vanishes, she has managed to demonstrate that the collapse of civilization caused by a fast - spreading pandemic cannot destroy the value of art. For art endures, adapts to, and transcends tragedy. Through Station Eleven Mandel thus offers her readers a way to consider what beauty, connection, human values are by claiming that the beauty we share through art and literature elevate our lives beyond simple survival.

It is the celebration of art and humanities. Art is such a human thing and it shines a light on the darkness of an apocalypse .... That is what Station Eleven is. It is a light on the darkness (54).

Therefore, Mandel takes her readers on a journey that questions many facets of art. For the survivors in Station Eleven, whether it is with Kristen's acting or the prophet's manipulative speeches, art is a way of transcending surviving, a way of finding a new passion, a new purpose, a new direction, and a new way of remaining human because "survival is insufficient (58)." After a performance of "A Mid Summer Night's Dream,'

[t]he audience rose for a standing ovation.

Kristen stood in the state of suspension ... a sense 


\section{of having flown very high and landed incompletely, her soul pulling upward out of her chest. A man in the front row had tears in his eyes (59).}

In the above quote, there is so much feelings and a sense of euphoria because of a form of art. After the collapse as well, everyone has faced great loss, has experienced an absence of something that was once important or loved, and has felt a sense of urgency to fill that void. For many survivors after the pandemic, this alternative or filler is art.

Art is a source of happiness for Kristen, the young actor - twenty years after the pandemic ripped through society- and for the Travelling Symphony, who decorate their caravan with the Star-Trek phrase "Because survival is insufficient," and who tour America performing plays to the survivors left behind. What is weird is that the people watching Shakespeare's productions after the collapse, despite the hardships of their lives and the world they know they have lost, still feel themselves part of the human story. Besides, Clark's museum curation is not just concerned with artifacts, it has become art. Miranda as well creates her comics in the absence of an audience for the sake of doing art: "What's the point of doing all that work," Tesch wonders, "if no one sees it? " Mirada responds: "It makes me happy. It's peaceful spending hours working on it. It doesn't really matter to me if anyone else sees it (92)." Another proof of the purity and value of art is that Miranda doesn't even sign her work, using her initials, "M.C." instead. And twenty - five years after Miranda's death, we see Kristen and Tyler are still captivated by her art. Add to this, realizing that they cannot really rely on anyone, but what they can rely on is a script, a pencil, or a clarinet reed, the survivors thus find solace and relief in this dependency upon art and realize this too:

There were moments around campfires when someone would say something invigorating about the importance of art, and everyone would find it easier to sleep that night (119).

As such, despite the immense loss from the pandemic, art - as Mandel claims is the most important thing in life: Art will never die or fade away like families or memories. Remnants of art still exist and are used to help humans connect to the past, have a purpose, and move in a way that transforms and inspires. These remnants remind humans that they actually have not lost everything, are still 
living, are still human, and can still feel beauty even in the most miserable of times. Overall, it is the amount of music, plays, paintings, and all forms of art in Station Eleven that measures how efficient and happy the society is. In the onset of the pandemic, art beings to decline (Arthur's death on stage is an indication) as society does. Nevertheless, when the Travelling Symphony begins to travel and share their arts, society begins to revive itself by returning back to its traditional ways while also embracing new customs.

Another way to maintain hope and capture the essence of life within Station Eleven is represented through Mandel's attaching importance to the role of faith. In the face of danger and struggle - Mandel shows - many characters turn to faith. Providing comfort and purpose and infusing continuity and persistence into a frantic changing world, faith becomes evident in the post - flu world as characters struggle to make sense of a catastrophe. Forgetting to look for a spiritual life as they went about daily life, these characters however are quick to find one when violently shaken by disaster. This is displayed in the ways the survivors value their various faiths and create their own belief systems in order to give meaning to their new world and bear the breakdown of their society. Amid the pandemic that leaves only a few survivors behind, the viewpoint that everything happens for a reason can be comforting, as it offers a justification for the mass death and mitigate the guilt of the survivors by making it clear that they deserve to survive.

Though faith can be the means of personal survival for some individuals, Mandel shows that it can become a means for power and control for others. Despite its many benefits, faith can also become extremely dangerous and can blind a character's judgment. Through the figure of Elizabeth, the murderous prophet and the rest of their cult, Mandel has offered a bleak example of the new religious order that twists the book of revelations and exploits the humans' need for religion to suit its own goals, exploit communities, gain political power, gather followers, take multiple young wives, and force will upon others. Nevertheless, through the (seeming) integration of Tyler's cult at the beginning as being "the light" and "the pure", Mandel illustrates the faith that Tyler brings - not only to himself but to his followers - in search of a better future. In praising the Georgian Flu as "the great cleansing," Tyler delivers hope for the survivors (the members of the town and the followers of his belief system as well). The prophet says, " We were saved" - his voice is rising - "not only to bring the light, to spread the light, but to be the light. We were saved because we 
are the light. We are the pure (63)." Besides, the downfall of the prophet is significant. When the prophet finally catches Kristen and prepares to execute her, the youthful follower of the prophet - with the gun in his hands- decides that he cannot stand to follow the prophet anymore and shoots him, though this young boy knows nothing other than this is not how humans should live. Moreover, despite the obvious perversion of traditional faith as shown by the prophet, Mandel shows that this is only a minor example of human nature's need for a belief system outside of their own practical life. August, for instance, who religiously prays over the dead bodies he encounters, wishing them peace, constructs parallel universes to ease the burden of the life he is living. "We can not only remain hopeful," he says, "we have to assume that the situation will become more clear (23)", and later on the whispers: "Have faith (261)." Furthermore, despite the disappearance of organized or traditional belief structure, faith in Station Eleven is manifested as well in the survivors at the airport who do not share the religious faith of Tyler and his mother but hold all things in common. It is the same faith that urges the Travelling Symphony to present Shakespeare and look for friends in St. Deborah. It is faith in greater future and in something unnamed, almost divine, that would prevail.

What is also remarkable about Station Eleven and emphasizes its utopian dimension is its appreciation of the miraculous beauty of modernity along with its endeavour to restore and rebuild human connections. Living in a technology - driven age, Mandel explores contemporary civilization through different lenses. Believing that there is no better way to consider our reliance on the innovations of the modern world than to take them away, Mandel uses Station Eleven's structure - with its intertwining story lines set before and after the collapse - to explore the contrast between life with and life without civilization.

Before the pandemic, civilization is shown as tedious, monotonous and even, suffocating or toxic. In the presence of civilization, humans are shown as 'zombies' sleep walking through life, completely severed from their environments and the people around them. Clark Thompson, for instance, interviews a young lady named Dahlia who finds faults in her boss Dan for his obsession with technology and corporate life. She clarifies how Dan - without realizing this - is wandering through life as a "high functioning sleep walker" and is thus living in a "corporate world full of ghosts" (161). Another clear example is the transition of Arthur and Miranda from their own small island to bigger cities where the disjunction between humans and nature is quite apparent. 
Besides, the difficulty both Arthur and Miranda manifest in their description of their own island to others highlights the way civilization separates human beings from each other. Moreover, though shown as appealing to Arthur and Miranda, civilization in Toronto is shown as dreary: The stars are obscured by light pollution, unlike the night sky of Delano Island which was filled with stars. Looking back at this society, Mandel describes it in terms of our technology: "when it was possible to press a series of buttons on a telephone and speak with someone on the far side of the earth (36)."

On the other hand, in the world after the collapse, devices and technologies - taken for granted twenty years earlier and used to be regarded as tedious and boring - are suddenly revealed to be incredible and get preserved as antiquities in the Museum of Civilization. In this world, Mandel attempts to stress the fact that in the absence of technology - air planes, television, radio or internet - people are truly physically disconnected from each other, unable to know what is going on in the world or even in the nearby town. Moreover, the way the survivors think about the civilization that has vanished shows to what extent humans used to rely with full confidence on civilization and yet emphasizes how many of civilization's marvels were taken by for granted. Hence, what the reader finds in Station Eleven is not the knocking down of the unscrupulous old world and the ensuing prelude to a utopian new world, but rather a lamentation about the bygone "wonders of technology (288)" and the "splendors of the former world (231)." This lament is quite evident - twenty years after the pandemic - when the survivors spend a moment at the light button, imagining that it might once more light up the room, only half believing that this was once possible: "As always in these moments she found herself straining to remember what it had been like when this motion has worked: walk inter a room, flip a switch and the room floods with light (69)." The lament is discernable as well in Clarke's musing: "why in his life of frequent travel had he never recognized the beauty of flight, the improbability of it? (247)" - a lament which is also echoed in Kristen's memories about the urban landscape seen from a plane at night. "Clusters and pinpoints of light in the darkness scattered constellations linked by roads or alone. The beauty of it (135)." Though lamenting the lost wonders of technology and its conveniences, Mandel urges us not to take modernity's benefits for granted.

Mandel also makes it clear that hope can be maintained through people themselves. While civilization has made amazing technological miracles, it is 
not technology that produces civilization - it is people. To those who undermine the people who develop our technologies; to those who bedim the material labour that serve as a foundation for the hyper connected globalized world, Mandel exhibits how the technological artifacts are human products, created by people.

We bemoaned the impersonality of the modern world, but that was a lie, it seemed ..., it had never been impersonal at all. There had always been a massive delicate infra structure of people, all of them walking unnoticed around us, and when people stop going to work the entire operation grinds to a halt (254).

Clark's reflections on the snow globe placed in the museum traces the production process of this object.

Consider the mind that invented those miniature storms of snow, the factory worker who turned sheets of plastic into white flakes of snow, the hand that drew the plan for the miniature Severn City with its church steeple and city hall, the assembly - line worker who watched the globe glide past on a conveyer belt somewhere in China. Consider the white gloves in the hands of the woman who inserted the snow globes into boxes, to be packed into larger boxes, crates, shipping containers (255).

Despite its advances, technology - as Mandel maintains in Station Eleven - kills relationships until nothing is left and causes severance with things that truly matter in life, without the individuals even realizing it. Though seemingly granting them independence, technology immerses the individuals in its obsession, undermines family values and relationships, breeds fewer face to face interactions, and thus leads to miscommunication and detachment. And through Mandel's own creative use of storytelling and character development, the idea that modern civilization and its technology destroy human connection is conveyed. By showing how the connected world can attain such miracles, Mandel also expresses the irony that this very interconnectedness is what causes the demolition of civilization. It is because our civilization is so developed and 
connected that the pandemic is able to expand rapidly and efficiently throughout the globe.

Mandel has managed to provide relatable insights into our fractured relationships through Dahlia's remark. Dahlia (the young woman interviewed by Clark) - once referring to this world as one full of ghosts - complains that people (like Dan) who are so obsessed with technology and lead their lives on their own have lost their ability to connect with others. A clear cut example of this isolation is further illustrated through Garett (one of the few survivors of the pandemic) who tells Clark about his past. Mandel quotes, "Garett had a wife and four - year - old twins in Halifax; but the last call he'd made was to his boss. The last words he'd spoken into a telephone were a bouquet of corporate clichés, seared horribly into memory (49)." Hence, Garrett's pre-occupation with the technological and corporate world has forced him - like many other people -to separate himself from his own family, without knowing it. That is not to suggest Mandel is advocating a return to the Stone Age. She is suggesting, instead, that technology should not be unreasonably used in our daily lives. She is reminding us how easy it is to be swept away by the flow of modern life, rarely recognizing that it is the relationships we build and not technological conveniences that truly enrich our lives and that sincerely need to be enhanced.

Jumping back and forth the Georgia Flu pandemic, Mandel has maintained another hopeful, utopian horizon by using memory as a frame work for her novel. Her aim is to create the idea that the past is very well embedded in the present. Believing that memory of the past would give way to the onset of the future, Mandel has rendered this notion true as the novel progresses, with more and more connections being drawn between Kristen and others around her. The connections between Kristen, Miranda, Arthur, Clark, and Tyler all come together once Kristen completes her journey to the Severn City Airport. Therefore, her journey is based on her desire to complete her ambiguous memories of the past.

Throughout Station Eleven, Mandel shows how memory can be a relief and a source of hope. Characters are thus shown as remembering and responding to their memories. This is quite evident when Kristen searches for books and gossip magazines in deserted homes to regain her memories of Arthur and the world she used to know to sustain her vision of that world alive. Likewise, the fact that Kristen even needs such memories testifies how losing one's memories can be a source of extreme anxiety. The Travelling Symphony, as well, are 
shown as preserving memories of the past by performing only Shakespearean plays, since their audiences seem to prefer his plays over more modern productions. As one performer puts it, "people want what was best about the world (38)" - a fact that speaks volumes of the timelessness of these productions.

It is not only Kristen and the Travelling Symphony who memorize in the novel, it is also Jeevan Chaudhary who muses extensively on his previous career as a paparazzo, including his meetings with Arthur that have led Jeevan to question the integrity of his work. Jeevan's answer as to "why he left tabloid news (10)" - when the paparazzi chase him for details of Arthur's death - "I want to do something that matters (10) " affirms Jeevan's new found dislike for that field. Thus, it is clear that Arthur - whose life Jeevan has tried to save - has changed Jeevan's perspective on life. Clark, as well, keeps memory of the past with his Museum of Civilization. It is here (in the museum) that wrecked airline passengers collect electronics, newspapers, passports and other items considered outdated. The survivors who inhabit the airport, thus, reflect on the past and the "limitless number of objects in the world that had no particular use but that people wanted to preserve (258)." Hence, the museum makes the survivors appreciate the pre-pandemic world, teach children who were born after the pandemic about human kind's achievements and history, and offer them a haven for their nostalgia.

But, whereas all the above yearnings for the past may suggest a nostalgic appreciation for a life that can never be restored, what Mandel in Station Eleven aims at - is not a going back to the exhausted past but resisting the over whelming force of such memories. Station Eleven thus critiques those who would completely surrender to the past's comforting embrace. It emphasizes as well that by reminiscing the past people 'sleep walk' through this new life, miss its true beauty, just as they once did the old one. Kristen affirms this view when telling Diallo "the people who struggle the most ... are the people who remember the old world clearly (195)."

Finally, Mandel's Station eleven offers another utopian possibility by suggesting that remembrance causes lack of fulfillment whereas imagination results in new possibilities. Hence, Mandel keeps on asserting throughout the narrative that imagination is something that humanity has in abundance, and that humanity has the desire not just to survive but to create new perspectives of the world. It is Miranda's comic book, Dr. Eleven, that suggests the value and 
primacy of imagination over remembrance. It offers Miranda an escape from the control of the male figures in her life - her former boyfriend Pablo, then her husband Arthur - before the flu's outbreak, and gives the novel its optimistic aspect.

It is unsurprising, thus, to notice a strong relationship and eerie parallel between Mandel's Station Eleven and the current outbreak of the Corona virus. Beside serving as a model and test case for understanding the cultural response to an apocalyptic pandemic, Station Eleven is considered uniquely relevant to the COVID-19 situation. For its tale has featured the same - if not more shocking pandemic tropes found in our current society: the hospitals overrun with victims, the halted businesses, and the abandoned airports. Besides, the pandemic — both in Station Eleven and in real life-reminds us that the social and cultural boundaries we use to structure our societies - are feeble and insecure, not stable and tight.

On the other hand, unlike the COVID-19 situation, the fictional virus featured in Station Eleven has flipped a switch from civilization to chaos, killing almost all who are infected; in addition to the cities that rotted away, the roads that gridlocked, and the electricity, internet, oil, and medicines that become nonexistent. Besides, where the incubation period of the Corona virus takes weeks, the incubation period of the Georgian Flu in Station Eleven is mere hours; and within a matter of days the entire world has become infected. Moreover, while Corona virus and lockdown have stimulated a sudden increase in the use of technology, the Georgian Flu has led to a post-technology world. The few survivors of the pandemic have to rediscover how to generate electricity and how to operate smartphones and credit cards on which they once relied.

Hence, through the lens of fiction, Mandel has strived to take her readers inside a world devastated by a global pandemic - similar to the COVID-19 pandemic. Though highly suspenseful, her Station Eleven does not use the pandemic for its shock value. She thus renders world events to sit in the background of her work. The pandemic in Mandel's novel dramatically emphasizes to the survivors how to live with and emerge from the pandemic, and how powerfully interconnected they truly are - the same thing the Corona virus is doing to us .For this purpose, Mandel's fictional pandemic holds a distorted mirror up to our lives, with the aim of rendering us really question our faith, creativity and human relationships; long for the world we live in right now; 
and better understand the way the pandemic sharpens complex, diverse, and multi-faceted fears about change (along with posing an immediate threat to our health) .

To sum up, though following the traditional politics of disaster of the dystopian pandemic fiction in wiping out much of the humanity, creating alternative realities and unfamiliar post-apocalyptic environments with reimagined, complex social structures, and highlighting the fragility of our existence, Mandel is a bit different in creating a vision of the world in the grips of a global pandemic that astonishes in its simplicity and decency. She creates what is possibly the most thought-provoking post- pandemic novel by taking her readers beyond statistics of global deaths and degree of spread, to teach them about the effect of these deadly manifestations on humanity. In other words, looking at the fictional pandemic as a moment of disruption or as an epidemiological fact - Mandel believes - is to have a narrow view of the future. That is why, the therapeutic details of the destructive virus in Station Eleven are less important than the human condition this novel is made for exploring. With such accelerated Georgian Flu, there is no battling for resources, "no war to be fought, no mobilizing force to save humanity...There is simply life before the collapse, and the largely empty world after (2014:38)." The remaining, tiny human population becomes intensely interesting, and so Mandel focuses her story solely on them.

Managing to demonstrate how the featured pandemic in Station Eleven is a symptom of something different - something profound, this study thus draws on Tom Moylan's concept of Critical Dystopia and Calder Williams' praxis of Salvage punk as relevant approaches, modes of resistance to, and means of living through this epoch of catastrophe. In a reality that has become chaotic, these approaches help Mandel to think through the possibilities and potentials, and perhaps paradoxically - provide a way of appreciating the graces of everyday life, finding comfort, envisioning hope, and keeping a utopian spirit. In an attempt to provide a model for thinking about the ruins, Mandel demonstrates how the survivors will live through this pandemic and, will ultimately recapture, repurpose, and recreate the world anew out of the colossal remains of discarded utopias. Accordingly, Mandel suggests the essential factors that would survive, or could be salvaged, and seem to make a life worth living: The ways of how to make from the broken same the livelier constructs of something other. 
Though vital, survival is not enough- according to Mandel. To survive she maintains - humans have to do more than just living. They need more than to eat, drink and breathe. They need to thrive, explore, challenge, and question themselves. They need to live as well as survive. But what could be salvaged according to Mandel - to make them recover a sense of normality, rebuild, and recreate the world a new?

Tapping into Tom Moylan's and Calder Williams's utopian possibilities of repurposing and recreating the world anew out of the wreckage that remains, Mandel maintains that human connection is among the fundamental aspects of life to be salvaged or to be considered necessary for survival in a time of societal chaos. The desire to be connected is manifested through the Travelling Symphony who band together to show people what was best about the world through their versions of Shakespearean plays. Tyler's leaving of the airport with his soon to be cult of 'religious wanderers' exemplifies as well how it is humans' nature to bond with those around and to yearn for a community to which one belongs. The establishment of the Severn City Airport as a place for a new community also demonstrates how the survivors prioritize the need to belong and be in the presence of others. Besides, the community of the airport helps Mandel highlight the importance of social ties in creating a fulfilling life and giving human lives meaning beyond a secluded existence.

Not only the people whom one loves and cares for are the ones who make life worth living. To lead a meaningful life - Mandel maintains - it is also important to live life for one's self: To be happy with the people in our lives and with ourselves. Miranda, for instance, does not find happiness until she begins to live for herself. The moment she realizes that she no longer has to shape her life around Pablo, her ex-boyfriend, she feels free. The same happens the moment she divorces Arthur: She feels then free enough to travel around the world and do things that she is interested in.

Purpose, faith, and the hopeful belief that tomorrow will be a better day are also crucial in making life worth living and in establishing a sense of self within the characters' lives. On analyzing each character, one realizes Mandel's genius. Clark, for instance, is among the survivors who look to new ways to define their world and who struggle to find purpose. At the beginning, he has gone through life as a ghost - just barely surviving. But it is not until the establishment of the Museum of Civilization that we truly see Clark happy. Tyler, as well, creates hope for himself though there isn't much to be hopeful 
about. Becoming the prophet, Tyler believes that humans were saved not only to bring, spread, and be the light. They were saved for being - themselves - the light. And, by becoming the light, Tyler essentially obtains the hope he needs to survive - not only for himself but also for his followers. Kristen and the rest of the Travelling Symphony, likewise, make their lives worth living. Although they have undergone difficulty, music and art give them joy and purpose. Kristen, in particular, copes with her new unfortunate life, infuses it with passion and purpose, and does all that is in her power to make the best of it rather than grieve endlessly for what she no longer has, and what she cannot have.

What can also be salvaged and make life worth living- according to Mandel - is art. Acting as a reminder of what humanity is capable of, art provides so many nuances to human existence and can be the best means toward cultivating a civilization and preserving our humanity. The art that the survivors fight to preserve in Station Eleven is a comic book, a musical interlude, a museum display, Shakespearean plays and classical symphonies - the things that we think of as the highest and most exalted expressions of our culture. By performing these works of art, the members of the Travelling Symphony preserve an important part of pre-collapse life and - in a subtle way - remind others of their humanity. The particular power of art Mandel celebrates is not, however, the power associated with its creation or consumption; it is the power of sharing art - the fact that Miranda has no expectation that anybody else will ever see her work. For her, the most important thing is the work of art itself, not whether or not it is ever published. The Travelling symphony's goal, as well, is not simply to read Shakespeare's plays or perform them for one another; it is to share them with audiences who may not have heard or seen them before. Thus as Mandel has demonstrated, art - in all its forms - can extract emotion from us, bring us into connection with others, change, challenge, build, and offer hope for us. Art will always survive through all disasters.

Acknowledging, revising, and repurposing the spirits of the past are other means of making life worth living. The spiritual connection with the past of technology and man - made institutions - Mandel believes - is a cognitive reminder that the world was once a place of equilibrium, and facilitates the reader towards recognizing the true conditions of the present. Nevertheless, though extolling the value of the pastwh, Mandel manages to offer hope not through a re-kindling of an exhausted past, but through a new imagined future in another world just out of sight. 
To conclude, Mandel in Station Eleven -by administering Tom Moylan's and Calder Williams' utopian approaches- rises above the gloominess of the usual dystopian novels, contributes to deconstructing nihilistic spirit, and assists in reconstructing alternatives. Exploring in detail life during, before and after the deadly pandemic, alternating between stories, scattering timelines, and then weaving the narrative together, Mandel suggests that destruction, disorder and horror are not terrible sustainable ways of life; thus making it seems plausible that there will eventually be some kind of hope. It is not, however, the kind of hope where one would eventually restore and restart society all over again. It is a different sort of hope. It is about what is to be chosen, salvaged and repurposed, what makes life meaningful, what allows people to flourish, and what is needed to live for. Hence, to view Station Eleven only as a prophetic look into the future is to miss the message that underlies Mandel's work, namely, revealing what lies buried within the rotten core of our present societies, recognizing what is worth holding onto, dismissing not the utopian potential of imagining things differently, and salvaging what fulfills, sustains, and nurtures us back to our best selves. 


\section{References}

- Alihodžić, Demir and Selma Veseljević Jeviković (2016). The Boundaries of Dystopian Literature. The Genre in Context. Bosnia and Herzegovina: OFF-SET d.o.o. Tuzla.

- Atwood, Margaret (2005). "Writing Utopia." In Writing with Intent. New York, NY: Carroll \& Graf Publishers.

- Baccolini, Raffaella and Tom Moylan (2003). "Conclusion: Critical Dystopias and Possibilities." In Dark Horizons: Science Fiction and the Dystopian Imagination. London: Routledge.

- Barnett, David (2016). "Books to Give You Hope: Station Eleven by Emily St. John Mandel." The Guardian, Aug. 18.

- BBC (2020). "Coronavirus: How are Lockdowns and Other Measures are being Enforced?' In BBC (ONLINE). [cited 18 March 2020] http://www.bbc.com/news/world-51911340.

- Beebe, Stephen (2013). The Logic of the Apocalypse. U.S.A.: The John C. Winston Co.

- Booker, M. Keith (1994). Dystopian Literature: A Theory and Research Guide. London: Greenwood Press.

- Demerjian , Louisa Mackay (2016)." Dystopia and the Promethean Nightmare." In The Age of Dystopia: One Genre, Our Fears and Our Future. London: Cambridge Scholars Publishing.

- Gilbert, Lauren (2014). "ALA's 2015 Best Lists." Library Journal, Sep. 01, Vol. 111 (14).

- Gottlieb, Erika (2001). Dystopian Fiction East and West: Universe of Terror and Trial. Montreal: McGill-Queen's University Press.

- Gueterres, Antonio (2020). "The Fury of the Virus Illustrates the Follyćć of War." UN News, March 23. https://unric.org/en/covid-19-we-areat-war-with-with-a-virus-un-secretary-general-antonio-gueterres/

- Harmon, Rod (1999). "Apocalypse When? The Warnings Rise." Chicago Tribune, Aug., 10.

- Hill, Andrew (2020). "Emily St. John Mandel: There's Something Taboo about Talking about Money." Financial Times, Oct. 23.

- Jameson, Frederic (2003). "Future City." New Left Review (21). 
- Lepore, Jill (2017). “A Golden Age for Dystopian Fiction: What to Make of Our New Literature of Radical Pessimism?" The New Yorker, May 29. http://www.newyorker.com/

(2020). "What our Contagion Fables Are Really about." The New Yorker, March 23. http://www.newyorker.com/

- Mandel, Emily St. John (2014). Station Eleven. London: Picador.

- Mead, Rebecca (2017). Margaret Atwood, The Prophet of Dystopia. The New Yorker, April 10. http://www.newyorker.com/

- Mehta, Tashan (2020). "Is the Pandemic Ensuring that the Future of Speculative Fiction lies in Today's Reality?" Publishing and the Pandemic. Scroll. IN.

- Miéville, China (2018). "A Strategy for Ruination". Boston Review, Jan. 8. http://bostonreview.net/literature-culture-china-miéville-strategyruination.

- Moylan, Tom (2000). Scraps of the Untainted Sky: Science Fiction, Utopia, Dystopia. Boulder, CO: West view Press.

- O'Leary, Stephen (1994). Arguing the Apocalypse: A Theory of Millenial Rhetoric. New York: Oxford University Press.

- Orwell,George (1987). Nineteen Eighty-Four. Boston, NY: Houghton Mifflin Harcourt.

- Oswaila, Jyoti and Kavita Vasdev (2021). "Emerging and Re-emerging Infectious Diseases - Past, Present and Beyond." MOJ Biology and Medicine, Vol. 6 (1).

- Rogers, Adrian (2015). " 'Station Eleven' Mandel's Love Letter to the World." The SpokesMan Review, Oct. 25.

- Rosenberg, Charles E. (1989). "What is an Epidemic? Aids in Historical Perspective." MIT Press, Vol. 118(2).

- Seidal , Jamie (2019) "Why we have Apocalypse on our Mind?" The Advertiser, Jan. ,01.

- Self, John (2020). Why People Are Turning to Pandemic Fiction to Help Process the COVID-19 Crisis." News Letter, April 01.

- Simons, Marlise (1988). "Books of the Time: Gabriel Garcia Marquez on Love, Plagues and Politics." New York Times, April 10.

- StableFord, Brain (1993). "Dystopias". In Culte, John \& Peter Nicholls (eds.). The Encyclopedia of Science Fiction $\left(2^{\text {nd }}\right.$ ed.) London: Orbit. 
- Stringer, Jenny (ed.) (1996). Apocalyptic Literature: The Oxford Companion to Twentieth - Century Literature in English. London: Oxford University Press.

- Vieira, Fortunati (2013). Dystopia(n) Matters: On the Page, On Screen, On Stage. Newcastle Upon Tyne: Cambridge Scholars Publishing.

- West, Mark (2018). "Apocalypse without Revelation? Shakespeare, Salvagepunk and Station Eleven." Open Library of Humanities, vol. 4.

- WHO (2020). "WHO Director - General's Opening Remarks at the Media Briefing on COVID-19." In WHO [ONLINE] [cited 11 March 2020] http://www.who.int/blueprint/priority-disease/keyaction/novel-coronavirus/en/ . "Corona virus Disease. (COVID-2019) R \& D." In WHO [ONLINE] [cited 25 March 2020] http://www.who.int/blueprint/priority-disease/key-action/novelcoronavirus/en/

- Willems, Brian (2018). "Punked Objects: Salvage punk in Perdido Street Station and Crumbs." Deletion:The Open Access Online Forum in Science Fiction Studies, May 28.

- Williams, Calder Evans (2011). Combined and Uneven Apocalypse: Luciferian Marxism. Roplay: Zero Books.

- Zakaria, Fareed (2020). Ten Lessons for a Post Pandemic World. London, United Kingdom: Penguin Books. 


\section{إعادة النظر فى الجائحة : إنتشال الأمل وإستخلاص جوهر الحياة فى رواية "المحطة رقم 11 الإيميلى سناتت جون ماندل}

المستخلص

تختص الورقة البحثية الحالية بدر اسة رواية "المحطة رقم الا" (2014) لإيميلى سـانت جون ماندل،

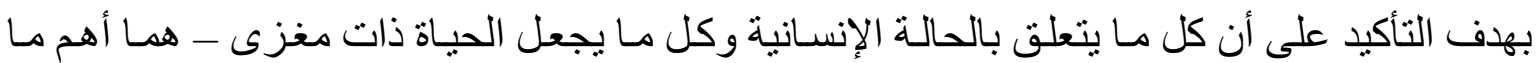

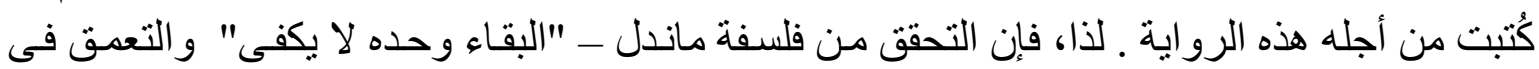

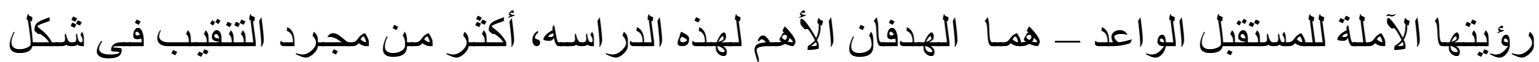

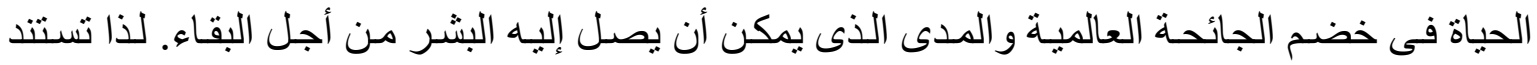

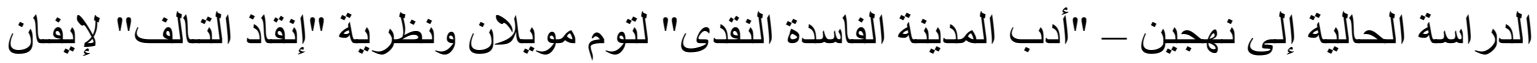

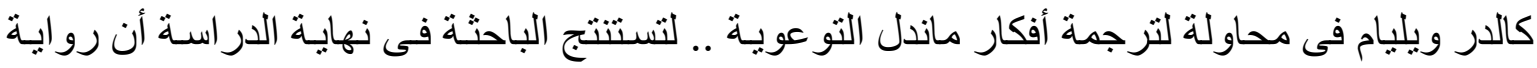

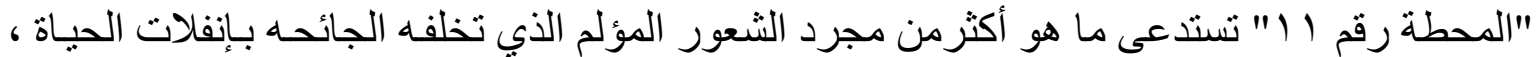
و ذلك من خلال إنتشال الأمل وإستخلاص هو هو هر الحياة مع التمسك بكل ما هو قيم وفاضل.

الكلمات المفتاحية الجائحة - نهاية العالم - نظرية "إنقاذ التالف" - مفهوم المدينة الفاسدة النقدى - إميلى سانت جون ماندل. 